\title{
Revisiting the "Responsibility to Protect" and the Use of Force
}

\author{
Mats Berdal
}

\begin{abstract}
Efforts to "operationalize" the Responsibility to Protect (R2P) continue to encounter resistance from key member states. Where it matters most, among vulnerable civilian populations caught up in war, the R2P appears to be making scant difference. Rising geopolitical tensions have added to a growing sense of pessimism among R2P advocates. Unsurprisingly, the most contentions aspect of the R2P concept continues to revolve around the question of the use of force for humanitarian purposes. It is a subject on which states, for an admixture of historical and political reasons, remain deeply divided. Nonetheless, as a politically significant norm, the R2P has come to command growing support from states, even though the degree to which the R2P norm has been truly internalized across international society varies greatly.
\end{abstract}

Keywords operationalizing R2P, NATO, Libya, Security Council, norm consolidation

\section{Introduction}

In June 2018, for the first time in nearly a decade, the United Nations (UN) General Assembly met in a formal session to debate the Responsibility to Protect (R2P). The debate, as António Guterres made clear in his opening remarks, took "place against a backdrop of atrocity crimes being committed at a scale and ferocity not seen in years, with little regard for international human rights and humanitarian law" (UN Secretary-General 2018). Since the divisive and controversial NATO-led intervention in Libya in 2011, a number of developments have only added to the widespread sense that the R2P is now "in a state of suspended animation, finely crafted in words but breached time and again in practice" (ibid.). Rising nationalisms, mounting evidence of a retreat from multilateralism and values-driven diplomacy, diminishing interest on the part of key powers in consolidating the normative gains of the 1990s, and profound political divisions within Security Council; all of these have combined to raise 
questions about the future of the R2P. Indeed, to many observers of the General Assembly debate, it looked as if the campaign to entrench the R2P "as a powerful new galvanising norm" (Thakur 2011) had come to dead end.

Against this, the present article examines the conceptual evolution and attempt at "operationalizing" the R2P from its immediate origins in the horrors of Rwanda and Srebrenica to the General Assembly debate in 2018. It is specifically concerned with the most contentious aspect of the concept and its history: the use of military force in a coercive capacity to protect populations at risk from mass atrocities.

Now, there is an obvious temptation, in light of the broad picture sketched above, to present the history of the $\mathrm{R} 2 \mathrm{P}$ in simple rise-and-fall terms: that is, as the story of how the horrors of Rwanda and Srebrenica concentrated the liberal conscience, stimulated conceptual innovation, and lead to a growing consensus around the idea of "sovereignty as responsibility" (Deng et al. 1996), culminating in the formal endorsement of the R2P idea by the General Assembly in 2005, only to be followed by the reassertion of power politics, a sharpening of great power rivalry, normative retrenchment, and growing resistance to the $\mathrm{R} 2 \mathrm{P}$ in the wake of the North Atlantic Treaty Organization (NATO)'s Libya intervention.

There is unquestionably a hard core of truth to this narrative. And yet, it can also simplify a more complex and nuanced picture, notwithstanding the profoundly inauspicious international political context within which the R2P is currently struggling to take root. Uncovering that complexity requires that a clear distinction-emphasized by Edward Luck while serving as Special Advisor to Secretary-General on the R2P in 2011 - to be maintained between understanding the $\mathrm{R} 2 \mathrm{P}$ as, on the one hand, a politically significant norm, principle, or standard of acceptable behaviour in international society, and, on the other, as an instrument of policy and actual "guide to tactical choices" (Luck 2011a, 388; $2011 b)$. In the former sense, the R2P has gradually come to command broad declaratory support from states, even though the degree to which the R2P norm has been truly internalized across international society varies greatly. In the latter sense, the R2P is mired in controversy. As is argued below more fully, however, when it comes to the question of the use of force-the principal focus of the present article-this is a controversy that is also inescapable, unlikely ever to be fully overcome or "resolved" by a doctrinal fix or further conceptual innovation. There is simply no prospect of agreement being reached among states on precise, watertight, and operationally meaningful criteria for exactly when and in what circumstances to use force in a coercive capacity for humanitarian purposes. This does not mean, however, that the R2P idea has lost all of its normative force and influence in international society, nor does it mean that the idea has not left a mark, in more indirect ways, on the calculations and policies of states and international organisations.

In developing these arguments, the article draws on both primary and 
secondary sources, and is divided into three closely connected parts.

The first of these examines key stages in the evolution of the R2P from its immediate origins in the "never-again" moment that followed the genocide in Rwanda and the mass slaughter in Srebrenica, through to the articulation of a carefully crafted and, in many ways, intellectually rigorous and impressive threepillar strategy for implementing the R2P, presented by the UN Secretary-General in 2009.

The second part looks in greater detail at NATO's military intervention in Libya, its consequences and wider significance. This is of more than just historical interest. Crucially, it helps to bring out-in ways that more abstract discussions of principles, process, and procedures cannot fully hope to do-the practical challenges, policy dilemmas, and moral conundrums raised by the use of military force for humanitarian purposes as these present themselves in real-world cases.

The third and final section places the post-Cold War evolution and current status of the R2P in a longer-term historical perspective. Although, as will be stressed, the grounds for pessimism are real and troubling, there is enough evidence to suggest that as a principle and expression of common humanity, the $\mathrm{R} 2 \mathrm{P}$ has not been confined to the historical graveyard.

\section{From the Rwanda Genocide to Security Council Resolution 1973}

\section{"Never Again"-The Immediate Origins and Evolution of the R2P, 1994-2005}

Over the course of some one hundred days in April and May 1994, an estimated 800,000 people, mostly Tutsis but also many moderate Hutu men, women, and children, were systematically slaughtered in Rwanda. The staggering scale, speed, and sheer horror of the Rwandan genocide remain difficult, if not impossible, to comprehend. What is clear is that it was foretold, carefully planned, and made possible by the passivity and indifference of the international community. Reflecting later on his experiences as Force Commander of the UN Mission in Rwanda (UNAMIR) before and during the genocide, Roméo Dallaire was adamant that "a great many opportunities to destabilize the génocidaires and derail the genocide" had been lost (Dallaire 2003, 514). "If UNAMIR had received the modest increase of troops and capabilities we requested in the first week," he insisted, the killings could have been stopped (ibid.). The independent Inquiry on UN actions in Rwanda released in 1999 concurred, arguing that "a force of 2,500 should have been able to stop or at least limit the massacres" (Carlsson, Han, and Kupolati 1999, 30). The efficiency and speed with which national evacuation operations by France, Belgium, the United States, and Italy were organized and carried out in mid-April 1994 confirm Dallaire's assessment: as a practical or technical proposition, reinforcing the mission was always an operationally credible option. The real obstacle to derailing the genocide, of 
course, lay elsewhere, specifically, in the lack of political will on the part of major powers to contemplate any form of proactive action that might have obstructed the génocidaires. The clearest and most striking manifestation of this disposition towards inaction in the face of mass slaughter was provided by the Clinton administration, which, on April 15, 1994, informed fellow Security Council members that "the international community must give highest priority to full, orderly withdrawal of all UNAMIR personnel as soon as possible" (United States Department of State 1994). On that very day, Dallaire reported back to New York that "a systematic extermination of Tutsis is taking place" behind the lines of Rwandese Government Forces (Force Commander, UNAMIR 1994), while UNAMIR's newly created Humanitarian Assistance Cell (HAC), also on April 15, reported "approximately 20,000 unburied bodies" in Kigali alone "as a result of widespread massacres" (HAC UNAMIR 1994).

The following year, in July 1995, a smaller, though no less horrific, mass atrocity crime was perpetrated in eastern Yugoslavia by Bosnian Serb forces under Ratko Mladić. Having overrun the supposedly "UN safe-area" of Srebrenica, Mladićs soldiers proceeded to execute some 8,000 of the pre-dominantly Muslim population of the town. As in Rwanda, the Srebrenica massacre dramatically exposed the failure of the international community, represented by the UN's troubled peacekeeping mission in Bosnia, to respond to mass atrocity crimes. In the searing words of the Srebrenica Report into the actions of the UN leading up to the massacre: "Through error, misjudgement, and an inability to recognize the scope of evil confronting us, we failed to do our part to help save the people of Srebrenica from the Serb campaign of mass murder" (UN Secretary-General 1999).

The realization that the use of military force might, at the very least, have helped to limit the scale of the slaughter in Rwanda and Srebrenica-and the sense of guilt which this induced in the Western liberal conscience-inevitably influenced the debate about the challenges of atrocity prevention after 1995. Although, as Adam Roberts $(2002-2003,159)$ rightly observed, neither in the case of Rwanda nor of Srebrenica "was there a major problem regarding the legality of intervention," in the soul-searching that followed those catastrophes, the principal impediment to the timely use of force in any future scenario was seen to lie in the "old orthodoxy" on intervention (Annan 1998). Kofi Annan, who had served as head of UN peacekeeping at the time of both Rwanda and Srebrenica, played a key role in challenging that orthodoxy, and, indeed, would come to view his principal achievement in office as having helped ensure that "respect for national sovereignty can no longer be used as a shield by governments intent on massacring their own people, or as an excuse for the rest of us to do nothing when such heinous crimes are committed" (Annan 2006; 2010; 2012).

While the issues of sovereignty and legality of intervention were not central to the failure to intervene in Rwanda and Srebrenica, NATO's military 
intervention to halt Serbian military action in Kosovo in 1999, justified on grounds of "overwhelming humanitarian necessity" but undertaken without prior Security Council authorization, did raise those issues starkly (Schnabel and Thakur 2000; House of Commons Foreign Affairs Committee 2000, $137-$ 175). While regretting the failure of the Security Council to reach an agreement on a collective response to the Kosovo crisis, Kofi Annan, speaking during the NATO campaign, nonetheless welcomed what he described as an emerging "international norm against the violent repression of minorities that will and must take precedence over the concerns of state sovereignty" (Annan 1999). While Annan accepted that "military intervention became necessary" in Kosovo (UN Secretary-General, 2000), to others-notably the Group of 77 (G-77) and non-aligned movement (NAM) grouping of states-NATO's decision to intervene without Security Council authorization represented little more than an arrogation of the "right to take arbitrary and unilateral action.... return to anarchy, where might is right"' (UN Security Council 1999, 15). ${ }^{1}$

The controversies over Kosovo are of special interest because they provided an important part of the background to the establishment of the International Commission on Intervention and State Sovereignty (ICISS), whose stated ambition was to help forge a "new international consensus" on the issues raised by the intervention for humanitarian protection purposes (ICISS 2001a). Proceeding from the principle that sovereignty implies responsibility (Deng et al. 1996), the central achievement of the Commission was to recognize the importance of language and seek to shift the terms of debate around the use force in defense of human rights. As Thakur and Thomas Weiss $(2009,46-47)$ would later put it, the responsibility to protect was chosen "because it was less confrontational and polarizing, more likely to lead to a consensus across the bitter NorthSouth divide." "Humanitarian intervention", they added, "approaches the topic explicitly from the Western interveners' perspective and isolates and privileges 'intervention"' (ibid.). By contrast the R2P is "victim-centred and surrounds intervention with prevention before and rebuilding afterwards" (ibid.).

Now, whilst an alternative to "humanitarian intervention" was found and widely appropriated, itself a significant achievement, at a deeper level, the ICISS report cannot be said to have overcome or reconciled the tensions at heart of previous debates about humanitarian intervention. In particular, while the "aim of providing precise guidance for states faced with human protection claims in other states" (ICISS 2001a, viii) was laudable, as Adam Roberts (2002-2003, 159) emphasised in his perceptive assessment of the Commission's final report, decisions with regard to individual cases invariably involve "a balancing of two important bodies of law-the one restricting the resort to force, and the other upholding human rights and humanitarian norms." Reaching prior and general agreement on how to achieve that balance poses the same kind of challenges for the $\mathrm{R} 2 \mathrm{P}$ as in the past it did for humanitarian intervention. 
There is a further consideration here relating to the ICISS report. The hope that a consensus could nonetheless be forged in spite of the inherent tensions alluded to above was based on the conviction that the end of the Cold War had resulted in "a new opportunity and capacity for common action" (ICISS 2001a, 7). Specifically, the commissioners felt there was now "a genuine prospect of the Security Council fulfilling the role envisioned for it in the UN Charter" (ibid.). "Globalization", the report asserted further, had also led to "a pronounced trend towards multilateral cooperation" (ibid.). This emphasis on new opportunities is both understandable and unsurprising in a blue-ribbon report of this kindindeed, highlighting them is arguably a key aspect of what blue-ribbon panels are about. And yet, both of these claims rested on assumptions about the irreversibility of trends in world politics that were ahistorical and questionable, something that the geopolitical fall-out from the events of $9 / 11$ and the subsequent 9/11-wars in Afghanistan and Iraq would soon demonstrate. The main point here, however, is a larger one: the tendency, especially pronounced in the 1990s, to view the end of the Cold War as a radical break or disjunction in world politics, also carried with it the tendency, whether implicitly or explicitly, to neglect the continuing importance of interest and historical memory as determinants of state conduct.

\section{The 2005 World Summit Outcome Document}

At a gathering of heads of state and government to mark the sixtieth anniversary of the UN in September 2005, the General Assembly agreed on an Outcome Document that formally endorsed the R2P (UN General Assembly 2005). Affirming, firstly, that "each individual state has the responsibility to protect its population from genocide, war crimes, ethnic cleansing, and crimes against humanity," Member States also agreed in principle to take collective action, "including under Chapter VII, should peaceful means be inadequate and national authorities manifestly [be] failing to protect their populations" from the aforesaid mass atrocity crimes (ibid., para. 138 and 139). The inclusion of the R2P paragraphs in the Outcome Document represented the crowning achievement of Annan's campaign to promote the R2P norm (Annan 2005, 2010).

The achievement should not be belittled or understated, however troubled the subsequent history of the R2P's implementation has proved to be. It marked the first time, as Michael Wood $(2006,8)$, Legal Advisor to the UK Foreign and Commonwealth Office between 1999 and 2006, noted not long afterwards, that the General Assembly had signed off on a qualification to sovereignty and accepted the idea that enforcement action to protect against massive human rights violation now falls within the remit of the Security Council without "reference to a need to find some international element" to justify intervention. As such, the paragraphs suggested general agreement on a standard of state conduct that covered behaviour also within the domestic jurisdiction of the state. 
Reaching agreement on this against the backdrop of the deep political divisions caused by the U.S.-led invasion of Iraq, which by early 2005 had descended into a catastrophic civil war, was itself a major achievement. ${ }^{2}$

And yet the significance of the R2P provisions in the Outcome Document can easily be exaggerated. There are three aspects to this that merit special attention.

First, the incorporation of R2P, although a politically significant commitment, was certainly not an automatic trigger for action, nor did it suggest that a general right of intervention on humanitarian grounds had been widely endorsed by member states. Indeed, states steered away from including a set of criteria to be applied when considering the possible use of force in situations where massive human rights violations were, or might be, committed, an approach that the ICISS had championed and Kofi Annan had also supported (Annan 2005; UN Secretary-General 2005). A careful reading of the relevant provisions and the accompanying commentary by member states also reveals much greater caution in other respects when comparison is made to the report of the ICISS and the Kofi Annan's own reform proposals (see Welsh 2006, 23-44; Luck 2010, 113 17). In particular, the Outcome Document firmly vested collective action under responsibility to protect in the Security Council acting under Chapter VII. Moreover, and as noted above, the Outcome Document limits the scope of R2P to four specific categories of atrocity crimes.

Second, agreement on the R2P formulation in the Outcome Document did not signify that policy elites in Russia and China-both permanent, vetowielding powers on the Security Council-had internalized the normative shift in favor of sovereignty as responsibility. For much of the 1990s, the so-called "P-3"the United Kingdom, France, and the United States-had been the permanent members that called the shots, made the decisions, and set the agenda on the Security Council. This dominance was also, however, a function of the fact that Russia and China were both deeply pre-occupied with major domestic challenges. Having inherited the Soviet Union's permanent seat on the Council in 1991, Russia remained in a position of relative weakness throughout much of the 1990s. The Chinese Communist Party for its part was preoccupied with the aftermath of the Tiananmen Square crackdown, seeking a new source of legitimacy by harnessing popular nationalism, promoting economic growth, and "reinventing itself as a developing state" (Mitter 2004, 290). Yet, both Russian deference and the comparative lack of Chinese involvement in Security Council affairs were never a reflection of a basic harmony of interests with other Security Council members, let alone a normative convergence around "solidarist values" (Mayall 2000). That it nonetheless appeared this way to some observers was a function of the fact, as Rana Mitter $(2003,234)$ noted with respect to China, that the "policymaking elite uses the language of international engagement to define its place in the world order of today; it talks in terms of human rights, international trade, 
and peaceful coexistence, while appropriating the meaning of those terms for its own purposes." In spite of this, profound and underlying fault-lines became more evident in the first half of the 2000s as both countries-against the backdrop of the Bush administration's response to $9 / 11$ - positioned themselves more vocally as counterweights to American power. The process whereby these translated into greater assertiveness and activism on the Security Council, however, was a gradual one and only came fully to the fore under Ban Ki-moon (Berdal 2014). It is true that, over time and especially since 2005, China has become more actively involved in the normative discourse around the R2P at the UN (Fung 2016). As discussed below, however, this greater engagement does not signify any fundamental modification or relaxation of China's ironclad commitment to the sanctity of the principle of sovereignty and the obligation of non-intervention.

Third, the willingness to sign up to the R2P in 2005, notwithstanding Russian and Chinese misgivings, widely shared by members of the G-77 and NAM, was also, quite plainly, closely linked to the fact that the document was entirely silent on the actual implementation of R2P principle. In particular, it offered no details on how military action might be triggered in response to a "manifest failure to protect." To that extent, the verdict issued by Mark Malloch-Brown $(2011,74)$ on the significance of the R2P's inclusion in the Outcome Document was basically right: "It was a tentative victory, grudgingly acknowledging that in extreme circumstance, if states abused their citizens on a mass and systematic basis, outside intervention might be necessary, but it was short on detail."

\section{Developing a Strategy for Implementing the R2P, 2005-2011}

Conscious of the "fledgling nature of agreement on Responsibility to Protect" (UN Secretary-General 2007), Ban Ki-moon, who replaced Kofi Annan as SecretaryGeneral in January 2007, set out to turn the "words of the 2005 World Summit Outcome into doctrine, policy, and, most importantly, deeds" (UN SecretaryGeneral 2009, para. 67). To this end, he ordered and oversaw the development of a detailed strategy paper- "Implementing the Responsibility to Protect"-aimed at reversing mounting criticism of and diminishing support for the concept, especially from those G-77/NAM states for whom the R2P was "becoming another version of humanitarian intervention" (Liu 2009). Operationalizing the $\mathrm{R} 2 \mathrm{P}$ was always going to be a tall order in the toxic political atmosphere following the World Summit, an atmosphere nourished by the war in Iraq and NATO's escalating involvement in Afghanistan. The key to it was seen, rightly, to lie in a renewed emphasis on R2P as "an ally of sovereignty, not an adversary," and, alongside this, an emphasis on the value and central importance of prevention (UN Secretary-General 2009, para. 10(a)). This emphasis was reflected in the report's conception of the R2P as resting on three "mutually supporting" pillars. Under the third pillar, the report acknowledged the need in extreme circumstances for a "timely and decisive response," including the robust use of 
military force to save lives. It placed equal stress, however, on the need for action under two other pillars: first, the state's own and primary responsibility to protect its citizens, and, second, measures of international assistance to strengthen the capacities of states to provide protection. The report discussed these by reference to a broad range of prevention and capacity-building activities and initiatives by the UN, citing examples from Northern Uganda to Kosovo (ibid., para. 28-48).

"Implementing the Responsibility to Protect" is an intellectually rigorous and impressive document, which credibly seeks to meet the concerns of the wider UN membership without sacrificing too much on substance. An important reason for this was undoubtedly that its author, Edward Luck-appointed Special Advisor on the R2P to Ban Ki-moon with responsibility for "conceptual development and consensus building" in 2007 (UN Secretary-General 2007) in 2007-came to the task with a clear-eyed appreciation, all too often missing in commentary on the $\mathrm{UN}$, of the importance of history and politics to an understanding of the how the organisation actually functions and, concomitantly, how neglect of history and politics has in the past invariably doomed reform to failure (Luck 2005). The lasting legacy of the report lies in the basic acceptance it has secured for the threepillar structure on which the R2P is seen to rest, even though, unsurprisingly, support for pillars one and two have proved much less controversial than pillar three (Luck 2011b). As India’s delegate to the 2018 General Assembly debate stated:

India, like many others, has little disagreement with the rationale of the cardinal features of the first and second pillars of the responsibility to protect. However, we are of the view that appropriate ways should be found to address the legally complex and politically challenging issues that underlie the third pillar. In our view, the ability of the international community to take appropriate collective action if a state manifestly fails to fulfil its responsibility to protect its population is still riddled with serious gaps that must be reflected on (UN General Assembly 2018, 13).

As several scholars have noted, China has, notably since 2005, become more actively engaged in debates and policy discussion about the R2P at the UN, employing solidarist language and gradually adopting what may be described as cautious and qualified support of the concept (Fung 2016). Crucially, however, Chinese advocacy for the R2P has focused, unsurprisingly, on pillars one and two in ways that have adroitly "allow[ed] it to appear cooperative and conciliatory without ceding ground on its vital interest to preserve sovereignty and restrict interventionist claims" (Teitt 2011,310). As one assessment of its growing engagement in the R2P debate notes, China has been "successful in reaffirming support for a state-centric system by narrowing the emerging principle" (Fung 2016, see also Fung 2019). This focus on the State's own and primary responsibility to protect remains central, and will remain so, to China's position. It is one that will only have been reinforced by the-in the eyes of the 
Communist Party leadership-deeply unwelcome light that has been shone on the widespread and systematic repression, justified on grounds of "combatting religious extremism and terrorism," of its ethnic Uighur community in the province of Xinjiang. Indeed, by mid-2019, evidence of growing repression led one prominent monitoring body to conclude that the Chinese government was itself "failing to uphold its responsibility to protect" (Global Centre for the Responsibility to Protect 2019, 15).

The deeper sources of the reservations expressed about pillar three, which remain widespread, are best explored in relation to the NATO's intervention in Libya and its wider political fallout.

\section{The Significance and Consequences of Libya}

On March 17, 2011, the UN Security Council authorized member states "to take all necessary measures...to protect civilians and civilian populated areas under threat of attack" from forces determined to crush a popular uprising against the internationally isolated and brutal regime of Mu'ammar al-Qadhafi (UN Security Council 2011b). Against the background of a deepening civil war, Resolution 1973, passed with five abstentions (Russia, China, Brazil, India, and Germany), provided the legal basis for Western-led military intervention to protect civilians at risk of large-scale atrocities in Libya. Within days, a bombing campaign, spearheaded by France, the United Kingdom, and the United States, was underway. ${ }^{3}$ Some seven months and more than 26,000 air sorties later, Qadhafi was captured and killed while in custody near his hometown of Sirte. Shortly afterwards, NATO's Secretary-General, meeting with the new Libyan leadership in Tripoli, announced the formal end of the alliance's combat mission.

Now, for advocates of the R2P, including eminent scholars who had helped develop and refine the principle over the previous decade, the Security Council's decision to authorize the use of military force was widely welcomed at the time as a defining moment, not merely in relation to Libya, but, crucially, also for the evolution of R2P itself. Writing a few days into the air campaign, Ramesh Thakur (2011), a distinguished scholar and member ICISS, had no doubt as to its significance: "Resolution 1973 marks the first military implementation of the doctrine of 'responsibility to protect.' Had the international community shirked this responsibility, Libya could have become R2P's graveyard." In early May 2011, Ban Ki-moon (2011), in an uncharacteristically impassioned speech, went further still: "what is happening in Libya, Cote d'Ivoire and elsewhere is an historic precedent, a watershed in the emerging doctrine of the responsibility to protect." And Gareth Evans, co-chair of the ICISS and former Australian Foreign Minister, considered Libya "an absolutely textbook case" for the R2P doctrine (Crossette 2012). 
It did not take long, however, for criticisms and doubts over NATO's motives and actions in Libya to set in. As the military campaign escalated and became more plainly geared towards the removal of Qadhafi from power, controversy about the way in which the R2P had been invoked, or was now being cited, to justify military intervention only intensified further. On the Security Council, criticism was led by India, Brazil, Russia, and China, all of whom had already expressed reservations about the vague and open-ended wording of Resolution 1973 (UN Security Council 2011c). South Africa, although it voted in favor of the use of force, quickly became an ardent critic of NATO's deepening involvement and what it too saw as a flagrant violation of the spirit of Resolution 1973. Echoing objections that, historically, had been at the heart of debates about the risks of humanitarian intervention-the dangers of abuse, selectivity, and inconsistency when intervening on what are ostensibly humanitarian grounds-these critics all came to view NATO's intervention less as a watershed moment for the R2P than a return to much older habits and practices of power politics.

Why did the Libya intervention move so rapidly from being a "text book case" to a highly divisive and controversial military operation, the political fallout of which continues to cast a long shadow over inter-governmental debates about and attitudes towards the R2P idea?

There are two levels at which the question and the controversies surrounding R2P's application in Libya needs to be approached. The first relates specifically to developments in Libya, and requires a clear distinction to be made between events leading up to the adoption of Resolution 1973 and its subsequent implementation. The second is related to the concerns held by a significant number of nonEuropean states (sometimes crudely labelled as belonging to the "Global South") about the deeper, unspoken objectives of Western military intervention in the service of justice and human rights. These concerns are rooted in a distinctive historical experience and memory of colonial rule and external incursion, as well as in more recent developments following the U.S. declaration of a "global war on terror" in response to the $9 / 11$ attacks. Together these provided a cognitive framework and a political context through which developments in Libya were interpreted. Their effect has been to magnify worries about the misuse of R2P by major powers.

\section{From Civilian Protection to Regime Change}

The wave of anti-government protests, street demonstrations, and popular uprisings which, beginning in Tunisia in late 2010, swept across much of the Middle East and North Africa, reached Libya in February 2011. Colonel Qadhafiin power for more than forty years but, by this stage, profoundly isolated internationally-responded to the stirrings of the Arab Spring in his country with the kind of savage ruthlessness that had long since come to define his regime (UN Human Rights Council 2011). His violent crackdown failed, however, to 
quell popular protests, which quickly escalated into a full-scale uprising and civil war. Alarmed by the ferocity of government's response to the uprising, the Security Council, in a unanimous resolution passed less than two weeks into the uprising, Resolution 1970, deplored the "the gross and systematic violation of human rights...against the civilian population made from the highest level of the Libyan government" (UN Security Council 2011a). Acting under Chapter VII, the Council referred the situation in Libya to the International Criminal Court (ICC), froze the assets of senior regime officials, and imposed an arms embargo (ibid., para. 4, 9, and 17). By the middle of March, with regime loyalists on the offensive and the city of Benghazi where the uprising had begun on the verge of being overrun, the Security Council passed a second resolution, Resolution 1973, on Libya, this time with a mandate "to take all necessary measures to protect civilians" (UN Security Council 2011b).

The immediate context within which Resolution 1973 was adopted was one of a fast-moving, confused, and rapidly deteriorating humanitarian situation on the ground. In late February, Navi Pillay, UN High Commissioner for Human Rights, stated that while reports were "still patchy and hard to verify, one thing is painfully clear: ...the crackdown in Libya of peaceful demonstrations is escalating alarmingly with reported mass killings, arbitrary arrests, detention and torture of protestors" (UN Human Rights Council 2011). "Patchy and hard to verify" and "escalating alarmingly", yet also "painfully clear": this, indeed, is how humanitarian protection crises often present themselves in the midst of unfolding violence and war. It is also why they place a premium on time-sensitive political decisions and actions, and leave limited time for exhaustive and fully informed consideration of "threshold" and "trigger" criteria for outside intervention. What was not in doubt in the weeks before the adoption of Resolution 1973 was Qadhafi's stated intention of showing "no mercy or compassion" to the citizens of Benghazi (Kirkpatrick and Fahim 2011). In view of the murderous and brutal history of his regime - a view that the picture emerging on ground in Libya in February and March only served to reinforce-there was every reason to take Qadhafi's threat seriously. On March 12, with the momentum of the regime's counter-offensive gathering pace, the League of Arab States declared its support for a no-fly zone, a decision that promised to lend legitimacy to Western-led action but also underscored growing and widespread alarm at the prospect of mass atrocities in Benghazi. It was against the background of these developments that France and the United Kingdom pushed for the adoption of Resolution 1973. The objective was immediate and short-term, not part of a deliberate and carefully worked out strategy to effect regime change. In the words of Mark Lyall Grant, UK Permanent Representative to the UN at the time, the prospect of a "bloodbath in Benghazi and a massacre of civilians" (House of Commons Defence Committee 2012, 88) could not be ignored. As Jean-David Levitte (2014), President Sarkozy's foreign policy advisor, put it: "another Srebrenica in North Africa" had to be avoided. 
This animating preoccupation with the immediate fate of Benghazi also emerges clearly from David Cameron's more recent recollection of events: "Benghazi was saved, and a Srebrenica-style slaughter was averted. I've never known relief like it" (Cameron 2019, 281; see also 275). Resolution 1973 explicitly excluded "a foreign occupation force of any form on any part of Libyan territory," a provision that appeared to further strengthen the R2P case for intervention (UN Security Council $2011 \mathrm{~b}$, para. 4). This, then, was the context that led observes and analysts at the time to conclude that the use of force under R2P was "ideally suited to the Libya situation, as it initially presented itself" (Eyal 2012, 55).

However, while regime change was not an original objective, it did not take long for the spirit and the constraints (vague as these were) of Resolution 1973 to be violated: an operation authorized "to take all measures necessary" to protect civilians became an exercise in regime change that involved actively taking sides in a civil war. This emerges clearly from an analysis of the nature and progress of NATO's campaign, where, as an early assessment put it, the "chief participants clearly aimed to engineer Gadhafi's downfall, but were unable to express this explicitly" (IISS 2011). Air strikes not only targeted government forces in retreat and in areas where they did not pose any obvious threat to civilians, but, as the war dragged on, they increasingly coordinated air operations with rebel activities on the ground, providing, in the final stages of the war, close air support for rebels. According to NATO's own figures, "approximately 6,000 military targets" were "damaged or destroyed" during the seven months campaign (NATO 2015). In defiance of previous Security Council resolutions, France, the United Kingdom, Qatar, and the United Arab Emirates soon began to supply arms and equipment to rebel forces. Of critical importance was the supply of weapons by France to rebels in the Nafusa mountains, reported and confirmed by the French government in June 2011 (France24 2011). These same countries, along with Egypt and the United States, also deployed Special Forces inside Libya from an early stage to assist with training, provide advice, and coordinate forward air control (RUSI 2011, 10-13; Taylor-Norton 2011). Adding powerfully to the anger of Security Council members that had abstained on Resolution 1973 now being stretched to secure the overthrow of the regime, France, the United Kingdom, and the United States closed down any further discussion in the Security Council about NATO's escalating involvement and the evolving situation in Libya (Puri 2016, 91). ${ }^{4}$

The speed with which the NATO operation expanded led many to view the civilian protection case made for Resolution 1973 as having been advanced in bad faith: protecting civilians was merely a cover for military intervention aimed at regime change. As suggested above, however, evidence does not support the view that intervention was a pre-planned exercise in regime change. Indeed, even Hardeep Singh Puri, privy to the internal Security Council debates on Libya at the time and one of the harshest and more eloquent critics of Western- 
led intervention in Libya, accepts that "the jury is still out on whether regime change was the original objective" (ibid., 103). Even so, there is no denying that Resolution 1973, as those who had abstained on the grounds of the widesweeping nature of its authorization to use force had feared, was interpreted in a way that allowed NATO to become a party to Libya's civil war. Those who had welcomed Resolution 1973 as the realization of the R2P had also warned against this very danger. Speaking at the start of the campaign, David Hannay (2011, column 1499) stressed the importance of "stick[ing] firmly to the mandate to protect," and warned "against being drawn into loose talk about targeting Gaddafi or speculating on the case for allowing mission creep to bring us towards regime change." Hannay's caution made perfect sense in R2P terms, the prism through which he viewed the significance of Resolution 1973.

And yet, insistence on carefully calibrated restraint underrates the dynamic effects set in motion by outside military intervention in an active civil war, even though the primary motivation for intervention is to protect civilians. In the case of Libya, civil war arose out of a spontaneous uprising against an oppressive and hated regime determined to crush its opponents. There was no political process on the ground and no prospect for a negotiated end to the war. In these circumstances, it is difficult to see how, once operations had commenced, the intervening powers-lacking an overall political strategy or defined political end state for the conflict in Libya - could have avoided being drawn into conflict. Even had NATO wished to stay above the political fray in an effort not to prejudge the outcome of the civil war, military intervention quickly acquired a logic of its own. As Michael Clarke $(2012,11)$ observed, "the military logic of enforcing the UN resolution effectively turned the coalition into the air arm of the rebels in a civil war." The consequence of this, the drift towards regime change, was evident, if not explicitly acknowledged, in the oxymoronic quality of the arguments advanced by President Obama, President Sarkozy, and Prime Minister Cameron in an article published less than a month into NATO's campaign. The aim of Resolution 1973, they stated, was "not to remove Gaddafi by force," and yet, as they also added, "it is impossible to imagine a future for Libya with Gaddafi in power" (Sarkozy, Obama, and Cameron 2011).

This leads to a further consideration. There was, in mid-March 2011, broad acceptance of the view that the prospect of mass atrocity crimes in Libya was real, and, accordingly, that UN member states were confronted with a strong prima facia case for the use of force under R2P. After all, Russia and China chose not to use their veto, while India, Brazil, and Germany all abstained rather than vote against Resolution 1973. The perceived excesses of NATO's subsequent campaign led a number of countries to stress the need, in any future R2P operation, for states also to exercise a "responsibility while protecting (RwP)" (Viotti 2011). This idea of RwP, as a distinct and separate concept, was formally presented to the Security Council by Brazil shortly after the end of NATO's mission, and quickly 
garnered wide support from member states. The Brazilian initiative is of interest in part because it gave voice to the "growing perception that the concept of the responsibility to protect might be misused for purposes other than protecting civilians, such as regime change" (ibid., para. 10). The measures proposed actually to avoid such misuse, however, while sensible and unproblematic at one level, have a tautological, even platitudinous, quality to them. Summarising the concept in 2012, in a report devoted to Pillar III of the R2P, the Secretary-General stated:

The essence of "responsibility while protecting" is doing the right thing, in the right place, at the right time and for the right reasons. Timely and decisive action puts a premium on assessment, on understanding what is happening, why it is happening, and how the international community can help keep a difficult situation from becoming worse" (UN Secretary-General 2012, para. 53).

The level of abstraction at which this statement is pitched makes it entirely uncontroversial. It provides no basis, however, for engaging with the hard and difficult questions posed by the Libya case as set out above, questions that do not lend themselves to simple answers, and to which member states-states, lest one forgets, with different national interests, policy priorities, and historical memories - are certain to offer a range of different, often competing, answers.

\section{The Significance of Historical Memory}

In Hope and Memory, the eminent historian Tzvetan Todorov closes his reflections on Europe's political history in the twentieth century with the controversies and substantive issues raised by NATO's intervention in the Kosovo conflict in 1999a Western-led military campaign initiated against a sovereign state, undertaken without Security Council authorization, and justified in the name of human rights. Seeking to explain why so many non-European countries-in Africa, Asia, and South America-were deeply wary of the "the right to interfere" on which NATO's action was premised, Todorov highlighted the "difference in historical memory" $(2005,275)$.

At least twice in their history European nations have invoked "principles and values" rather than national interest to justify actions taken outside their borders. And on both occasions they acted out of the conviction that they were proprietors of the good, whereas distant countries, on other continents, were allowing evil to flourish on their soil. So the Europeans sent off their armies to try to impose good on others (ibid.).

Historical memory, Todorov implies, acts as a frame of reference through which contemporary developments are filtered and interpreted, shaping both the perceptions of interest and the hierarchy of values that govern the priorities and behavior of individual states within the international system. The historical 
experiences on which memories and narratives are based provide a particularly important context for understanding concerns long held by G-77/NAM countries about any weakening of the principle of sovereign equality and its corollary the rule of non-intervention; principles and rules which together are seen to perform a vital protective function vis-à-vis more powerful states. Disagreements and tensions over the operationalization of the R2P, and quite especially over the military implementation of the doctrine in Libya, have inevitably reflected these differences in memory and experience. Thus, when France's Foreign Minister, Bernard Kouchner, in May 2008, suggested that the R2P should be invoked to enable the delivery of aid to cyclone-hit Myanmar without the approval of the military junta in the country, the reaction was entirely predictable (Parsons 2008). Similarly, when the U.S. delegate in the General Assembly discussion on the Secretary-General's report on Pillar III of the R2P, in September 2012, chose to emphasize how that report "underscores [that] 'coercive measures should neither be left out of our comprehensive strategy nor relegated to use only after other measures have been tried and found inadequate"'(United States Mission to the UN 2012), it was certain to be interpreted in a particular way, even though, technically, there was nothing inaccurate in the statement and the wider point that was being made.

Now, Todorov is not alone in having pointed to the importance of historical frames of reference. Indeed, the background documentation prepared for the ICISS was careful to acknowledge how "powerful states have a long history of fabricating and employing tendentious legal arguments to rationalize intervention in weaker states" (ICISS 2001b, 67). And yet, among Western policy-makers, including advocates for action in Libya and earlier Kosovo, the wariness detected by Todorov has frequently been dismissed as disingenuous and self-serving, little more than an excuse for failing to take action in response conscious-shocking violations of human rights. Why? There are, it would seem, two answers to this.

The first, quite simply, is that the charge of disingenuousness, drawing attention to the essentially self-serving character of objections to entrenching the R2P norm, cannot be dismissed out of hand. The fact that Russia and China in their capacity as permanent members of the Security Council have presented themselves, however implausibly, merely as disinterested and principled defender of the UN Charter and its order-related provisions, specifically the rule of nonintervention, invites, justifiably so, both cynicism and suspicion. In neither country, as noted above, have the political and decision-making elites embraced the conception of human rights and the conditional nature of sovereignty on which the case for R2P is based. The larger point here, however, goes beyond Russia and China. The list of countries with a poor to lamentable human rights record is long and includes many of those who have proved particularly resistant to the R2P norm, fearing that to do so would only widen scope for outsiders to pry into their domestic affairs. Resistance to intervening in defense of human 
rights should always be scrutinized for the admixture of motives it reflects.

There is, however, a further dimension to this. The tendency to dismiss the concerns of non-Europeans (including India, Brazil, and South Africa, all on the Council during the Libya crisis) also reflects a deeper failure on the part of political and decision-making elites within former imperial powers, most notably Britain and the France-both permanent Council members and both ardent champions of the $\mathrm{R} 2 \mathrm{P}$ - to acknowledge, let alone engage critically, with the more uncomfortable and complex legacies of their Empires, including the reality that, in the words of Mark Mazower (2011), "human rights do not form an eternal language, they are enmeshed, whether we like it or not, in past European imperial forays." A detailed exploration of the historical and cultural reasons for this failure is beyond the scope of the article, though it should be stressed that the issue is not merely one of right-leaning historians and commentators extolling the virtues of Empire. Indeed, in the case of the United Kingdom, historians have played a vital role in documenting not only the brutality of colonial rule, but also the racist underpinnings and violence at the heart of Empire (see Anderson 2005). The obstacle to understanding the importance of historical memory also lies, as William Dalrymple (2015) has perceptively noted, in "the opposite, liberal, tendency to recoil from all memory of empire and to simply ignore and forget it," resulting in "willful obliviousness in Britain about the darker side of its imperial past."

Added to this, but also closely linked to the longer-term historical concerns alluded to above, worries about the misuse of the R2P by more powerful states must also be seen in the context of post-9/11 developments, in particular the anxieties generated by doctrine of pre-emption promulgated by the U.S. administration in the aftermath of $9 / 11$ and the basis for use of force in its "Global War on Terror." It is sometimes forgotten that the AUMF (2001), the joint resolution passed by Congress on September 14, 2001 that gave the president sweeping powers to use "all necessary and appropriate force" to "prevent any future acts of international terrorism against the United States," is still in effect. And, as Falkenrath (2017) has observed of the AUMF:

Whilst it was primarily a de facto and immediate declaration of war against Al-Qa'ida, it was also a much more open-ended legal construction that authorized the President to use force in an extraordinarily broad set of circumstances with no end date set on the use of force, nor restrictions laid on the geographical locations and nationality of the targets (Falkenrath 2017, 73-74).

And yet, for all this, recognizing the role of historical memory, its impact on the hierarchy of values and perceptions of interest among states, is not tantamount to rejecting the universalism of human rights. Returning to Todorov $(2005,278):$ "The issue here is not the universality of rights and values, but their 
practical implementation in real societies-not ends, but means." That, as shown above, has also been, and remains, a central challenge facing the R2P.

\section{R2P and the Use of Force for Human Protection Purposes: Stocktaking and Prospects}

When the General Assembly met in June 2018 to debate the R2P, wider geopolitical trends, internal political developments in key member states, and the stark realities faced by record-numbers of civilians caught up in war and violence were all combining to raise profound questions about the future of the R2P. The grounds for concern were multiple: the dire state of political relations among major powers, as reflected in the near-complete breakdown of Security Council cooperation on issues of peace and security; evidence of a diminishing commitment to values-driven diplomacy and multilateralism, epitomized, symbolically, by John Bolton's elevation to the post of U.S. National Security Advisor in 2018; and, above all, evidence pointing to a worsening situation for civilians and vulnerable populations in zones of conflict. Nearly 70 million people were forcibly displaced as a result of "persecution, conflict, violence, or human rights violations" in 2017, the highest number ever recorded by the UN's refugee agency (UNHCR 2018, 2). At the same time, a number of delegates to the R2P debate in New York continued to express concerns about the "political instrumentalization or exploitation" of R2P's "noble objectives" (UN General Assembly 2018, 18). There is no denying the reality of these trends and their adverse implications for attempts to further strengthen the R2P.

And yet, while the grounds for pessimism are real, the temptation to write the story of the R2P in simple rise-and-fall terms, or as some are now wont to do, a lost opportunity, is itself problematic.

One reason for this is simply that some of the early optimism about the R2P's galvanizing potential as an emerging norm in international relations always rested on an overly sanguine view of wider trends in world politics, underplaying, in particular, the continuing importance of interest and historical memory as determinants of state conduct. This gave rise to expectations unlikely to be fulfilled; expectations that did not fully recognize the extent to which progress in international affairs does not lend itself to simple linear measurement, is always susceptible to reversal, and is often double-edged and ambiguous. The importance of interest and history also provides part of the reason why agreement among state on the precise criteria for the use military force for humanitarian purposes has proved, and will continue to prove, elusive.

None of this is to suggest that progress in international relations is necessarily a chimera, and, indeed, there are other, more positive grounds for challenging the view that the $\mathrm{R} 2 \mathrm{P}$ project has reached a dead end. This, too, requires a longer-term 
historical perspective. It also requires, as noted at the outset, a clear distinction to be drawn between the R2P as standard or norm, and as a prescriptive guide to action and policy. For reasons explored above, the latter was always likely to run into difficulties. The former is a different matter.

Paradoxically, part of the evidence for this is offered by the Libyan crisis itself. As violence was escalating and the humanitarian crisis deepening in February and March 2011, Russia and China along with South Africa, Brazil, and India, all chose to vote in favor of Resolution 1970. In so doing, they recalled "the Libyan authorities' responsibility to protect its population," and noted that "the widespread and systematic attack currently taking place... against the civilian population may amount to crimes against humanity" (UN Security Council 2011a). In terms of the evolution of ideas about what is and what is not acceptable behavior in international society, the unanimous adoption of Resolution 1970 is more revealing than Resolution 1973 that authorized NATO action.

In April 2014, the Security Council unanimously voted in favor of establishing a new, ambitious, and large-scale peacekeeping operation for the Central African Republic (CAR) under Chapter VII of the UN Charter. It did so in response to "multiple violations of international humanitarian law and widespread human rights violations and abuses," and it placed the protection of civilians (POC) at risk from mass atrocity crimes right at the centre of its mission (UN Security Council 2014a). Addressing the General Assembly in 2018, António Guterres specifically referred to the Council's decision to act in CAR as "a positive example set by the international community... when there was a high risk of a genocidal killing spree" (UN General Assembly 2018, 3). Also in April 2014, the Council, following an intense debate over precise wording, passed a resolution marking the twentieth anniversary of the start of the Rwanda genocide. This resolution too was passed unanimously. It called on states to "recommit" themselves "to prevent and fight against genocide, and other crimes under international law," and, more significantly, explicitly reaffirmed the relevant paragraphs of the 2005 World Summit Outcome Document "on the responsibility to protect populations from genocide, war crimes, ethnic cleansing and crime against humanity" (UN Security Council 2014b). Significantly, both resolutions were passed little more than a month after Russiass illegal annexation of Crimea had brought relations between Russia and Western Council members to a new low.

The Secretary-General's aforementioned reference to the UN's lifesaving role in CAR highlights another way in which the R2P idea has impacted, more indirectly, on policy, specifically on UN peacekeeping policy. The basic acceptance of POC as a core task, not merely an ancillary function, of UN peacekeepers since 1999 point to a wider shift in the normative assumptions surrounding UN peace operations, however troubled and uneven in practice has been the implementation of individual POC mandates. In the case of South Sudan, the 
UN Mission, whilst profoundly overstretched and under-resourced, saved tens of thousands of lives in 2013 and 2016 through the establishment and maintenance of POC sites (NUPI 2019, 58-60; see also UN Secretary-General 2019). According to one authoritative study of the United Nation's Mission in South Sudan (UNMISS)'s performance, a widely expressed sentiment among South Sudanese is that UNMISS, by opening POC sites to offer physical protection, averted a genocide in the country in 2013 and 2016 (NUPI 2019, 3). The attitude of member states and the concrete actions taken by UN on the ground in order to protect lives both in CAR and South Sudan-the sense that such action was both necessary and right-contrast sharply with comparable cases from the early postCold War period, most notably the experience of UNAMIR in Rwanda, and, as such, provide some evidence of a change in normative context and expectations. ${ }^{5}$

The extent to which attitudes and normative assumptions have shifted emerges still more clearly when a longer-term historical perspective is adopted. Vietnam's invasion of Cambodia in December 1978 brought an end to the regime of Pol Pot. Awareness of the scale of the horrors perpetrated by Pol Pot's regime may explain why, even though Vietnam did not seek to justify its invasion on humanitarian grounds, several Western members on the Security Council in the debate that followed the fall of Phnom Penh, decided to address the issue of whether or not Vietnam's invasion could be justified on humanitarian grounds. ${ }^{6}$ Their conclusion could not have been more unequivocal. "Whatever is said about human rights in Kampuchea," the UK representative made clear, "it cannot excuse Vietnam...for violating the territorial integrity of Democratic Kampuchea” (UN Security Council 1979). Australia similarly insisted that "the internal policies of any Government, no matter how reprehensible" could never justify outside military intervention (ibid.). The Cold War context and the fact the United States itself had recently suffered a traumatic defeat at the hands of Vietnam must necessarily be factored into the analysis of the 1979 Cambodia debate. Even so, the categorical rejection of the argument that the domestic policies of a government, when these involve mass atrocity crimes, cannot justify outside military intervention is something that the basic and general acceptance of the $\mathrm{R} 2 \mathrm{P}$ norm has made untenable. If so, then the aforementioned considerations lend some support, it would appear, to Thomas Franck $(2003,204)$ 's view on how international law itself is evolving: as a process to be "understood in less absolute and more dynamically transactional terms, as a system of norms constantly engaged in a process of challenge, adaptation, and reformulation."

\section{Concluding Reflections}

In November 2012, an Internal Review Panel on the actions of the UN during the final stages of the Sri Lankan civil war was unsparing in its criticisms of the 
organization's failure to "meet protection responsibilities" towards civilians caught up in the conflict. Among its findings, the final report also noted that the UN's response was not helped by "frequently inconclusive discussions on the concept of the Responsibility to Protect" (Secretary-General's Internal Review Panel on UN Action in Sri Lanka 2012, para. 77). The report was detailed and meticulous in its coverage, and much of the criticism contained in it, especially that relating to the UN's "systemic failures" in response the evolving humanitarian crisis in Sri Lanka, was warranted. Its findings prompted welcome and potentially significant initiatives aimed at improving UN's capacity to respond in the future, including the "Human Rights up Front" initiative launched by the Secretary-General in 2013.

There is, however, a further aspect to the so-called "Petrie Report" on the UN failures in Sri Lanka that merits attention in the context of the present article. For all its detail and undoubted value as an account of events in which as many as 40,000 civilians may have been killed, it also appeared to rest on a fundamentally flawed assumption: "All Member States regret and would wish to prevent situations where there is large-scale loss of human life" (ibid., para. 86). Whether or not this striking sentence was inserted to placate politically sensitive member states, the historical and contemporary record show it to be profoundly wrong. Had it been otherwise, the challenge of operationalizing or implementing the R2P would have been far more straightforward, a mere technical and organizational challenge. Yet, the uncomfortable truth is that a distressingly large number of states and non-state actors have shown, and continue to show, neither regret nor willingness to prevent "large-scale loss of human life." The horrors of Rwanda and Srebrenica have been followed by numerous other mass atrocity crimes. It is for this reason, above all, that efforts to entrench the R2P norm, despite setbacks and inauspicious geopolitical circumstances, must continue. Consensus on implementing the norm will continue to prove elusive but the discussion itself remains vitally important.

\section{Notes}

1. It needs to be stressed that references throughout the present article to the G-77, the NAM, and the "Global South" are not meant to imply complete uniformity and consistency of views across what is a large and diverse body of UN member states. The terms are used here to convey a particular-widely shared and historically rooted-attachment to the order-related provisions of the UN Charter. Of the G-77 and NAM, it might also be added that, while they have largely outlived their original purposes, they have found a new lease on life as inter-governmental caucuses articulating the views, and seeking to coordinate the positions, of the "Global South" within UN forums and conference settings.

2. A good insight into the tensions and toxic atmosphere surrounding the World Summit can be gained from John Bolton's account of his time as Permanent Representative 
of the United States to the UN in 2005 and 2006, a book tellingly, if also curiously, entitled Surrender is Not an Option (see Bolton 2007, chapter 7).

3. Initially under U.S. command, NATO took charge of the Libyan air campaign, renaming it Operation Unified Protector, on March 31, 2011.

4. Hardeep Singh Puri served as India's Permanent Representative to the UN in New York from 2009 to 2013, and represented India as a non-permanent member of the Security Council in 2011 and 2012.

5. This is not to say that mass atrocities have not continued to be perpetrated in South Sudan and CAR, nor is it meant to imply that the protection crisis in either of one of the countries is no longer acute (Global Centre for the Responsibility to Protect 2019, 13).

6. None of the ASEAN countries-Malaysia, Indonesia, Singapore, the Philippines, and Thailand-made reference to mass atrocities committed by Pol Pot's regime.

\section{References}

Anderson, David. 2005. Histories of the Hanged: Britain's Dirty War in Kenya and the End of Empire. London: Weidenfeld and Nicholson.

Annan, Kofi. 1998. "Reflections on Intervention.” Ditchley Park Lecture, June 26.

Annan, Kofi. 1999. “Standing up for Human Rights.” UN Commission on Human Rights, Geneva, April 7.

Annan, Kofi. 2005. “A Glass at Least Half-Full." Wall Street Journal, September 19.

Annan, Kofi. 2006. "In Truman Library Speech, Annan Says UN Remains Best Tool to Achieve Key Goals of International Relations.” December 11. https://www.un.org/sg/ en/content/sg/speeches/2006-12-11/truman-library-speech-annan-says-un-remainsbest-tool-achieve-key (accessed October 30, 2019).

Annan, Kofi. 2010. Interview with author, Geneva.

Annan, Kofi. 2012. Interventions - A Life in War and Peace. London: Allen Lane.

AUMF (Authorization for Use of Military Force). 2001. Public Law 107-40, September 18. https://www.govinfo.gov/content/pkg/PLAW-107publ40/pdf/PLAW-107publ40.pdf (accessed October 30, 2019).

Ban, Ki-moon. 2011. “Address to the Sofia Platform." May 6. https://www.un.org/sg/en/ content/sg/speeches/2011-05-06/address-sofia-platform (accessed October 28, 2019).

Berdal, Mats. 2014. “The United Nations, Peacekeeping and Power Politics: Is the West Still in a Position to Impose Its Vision on Emerging Powers?" Geneva Centre for Security Policy. https://www.files.ethz.ch/isn/163961/Mats\%20Berdal\%20Final.pdf (accessed October 28, 2019).

Bolton, John. 2007. Surrender is Not an Option: Defending America at the United Nations and Abroad. New York: Threshold Editions.

Cameron, David. 2019. For the Record. London: William Collins.

Carlsson, Ingvar, Sung-Joo Han, and Rufus M. Kupolati. 1999. "Report of the Independent Inquiry into the Actions of the United Nations during the 1994 Genocide in Rwanda." S/1999/1257, December 15.

Clarke, Michael. 2012. “The Making of Britain's Libya Strategy.” In Short War, Long Shadow: The Political and Military Legacies of the 2011 Libya Campaign, eds. Adrian Johnson and Saqeb Mueen. London: RUSI, 7-14. 
Crossette, Barbara. 2012. "The Responsibility to Protect Gets a Checkup." PassBlue, January 21. https://www.passblue.com/2012/01/21/the-responsibility-to-protect-gets-acheckup/ (accessed October 28, 2019).

Dallaire, Roméo. 2003. Shake Hands with the Devil. Toronto: Random House.

Dalrymple, William. 2015. "Facing Up to the Past." Guardian, November 21.

Deng, Francis M., Sadikiel Kimaro, Terrence Lyons, Donald Rothchild, and I. William Zartman. 1996. Sovereignty as Responsibility: Conflict Management in Africa. Washington, DC: Brookings Press.

Eyal, Jonathan. 2012. “The Responsibility to Protect: A Chance Missed." In Short War, Long Shadow: The Political and Military Legacies of the 2011 Libya Campaign, eds. Adrian Johnson and Saqeb Mueen. London: RUSI, 53-62.

Falkenrath, Richard A. 2017. "Deterrence and Democracy: Reflections on American Post9/11 Homeland Security." In The Art of Creating Power: Freedman on Strategy, eds. Benedict Wilkinson and James Gow. London: Hurst \& Co., 73-84.

Force Commander, UNAMIR. 1994. "The Political/Military Assessment of the Situation as of 16 April 1994, Dallarie (UNAMIR) to K.Annan (DPKO), 15 April 1994.” Code Cable.

France24. 2011. "French Military Confirms Airdropping Arms to Libya Rebels." June 29 https://www.france24.com/en/20110629-french-military-confirms-airdroppingarms-libya-kadhafi-rebel (accessed May 3, 2019).

Franck, Thomas. 2003. "Interpretation and Change in the Law of Humanitarian Intervention." In Humanitarian Intervention - Ethical, Legal, and Political Dilemmas, eds. J. L. Holzgrefe and Robert O. Keohane. Cambridge: Cambridge University Press.

Fung, Courtney J. 2016. "China and the Responsibility to Protect: From Opposition to Advocacy." Peace Brief, USIP, June. https://www.usip.org/publications/2016/06/chinaand-responsibility-protect-opposition-advocacy (accessed November 28, 2019).

Fung, Courtney J. 2019. "Rhetorical Adaptation, Normative Resistance and International Order-making: China's Advancement of the Responsibility to Protect." Cooperation and Conflict, June. https://doi.org/10.1177/0010836719858118 (accessed November 28, 2019).

Global Centre for the Responsibility to Protect. 2019. "R2P Monitor, Issue 47." September 15. http://www.globalr2p.org/media/files/r2p_monitor_sept2019_final.pdf (accessed October 28, 2019).

HAC (Humanitarian Assistance Cell) UNAMIR (United Nations Assistance Mission for Rwanda). 1994. "OPS Plan on Humanitarian Assistance for Rwanda." Attachment to Fax (MIR-771) from Dallaire (UNAMIR) to Annan (DPKO), April 15.

Hannay, Lord. 2011. "House of Lords Debate, Friday 1 April 2011." https://publications. parliament.uk/pa/ld201011/ldhansrd/text/110401-0001.htm (accessed October 28, 2019).

House of Commons Defence Committee. 2012. Operations in Libya, Vol. 1. London: House of Commons Defence Committee.

House of Commons Foreign Affairs Committee. 2000. Fourth Report: Kosovo Volume II. HC 28-II, May 23, Session 1999-2000. London: The Stationary Office.

ICISS (International Commission on Intervention and State Sovereignty). 2001a. The Responsibility to Protect: Report of the International Commission on Intervention and State Sovereignty. Ottawa: International Development Research Centre. 
ICISS (International Commission on Intervention and State Sovereignty). 2001b. The Responsibility to Protect: Research, Bibliography, Background: Supplementary Volume to the Report of the International Commission on Intervention and State Sovereignty. Ottawa: International Development Research Centre.

IISS (International Institute for Strategic Studies). 2011. "Early Military Lessons from Libya.” IISS Strategic Comments 17 (34), September.

Kirkpatrick, David, and Kareem Fahim. 2011. "Qaddafi Warns of Assault on Benghazi as UN Vote Nears." New York Times, March 17.

Levitte, Jean-David. 2014. "Remarks during the UNU-UNESCO Panel Discussion: Responsibility to Protect, Sovereignty, Long-term Responsibility." UNU-UNESCO Conference "21st Century Wars, 2003-2014," Paris, February 27.

Liu, Zhenmin. 2009. "Statement by Ambassador Liu Zhenmin at the Plenary Session of the General Assembly on the Question of 'Responsibility to Protect." July 24. http://www. china-un.org/eng/hyyfy/t575682.htm (accessed October 28, 2019).

Luck, Edward C. 2005. "How Not to Reform the UN." Global Governance 11 (4): 407-14.

Luck, Edward C. 2010. "Building a Norm: The Responsibility to Protect Experience." In Mass Atrocity Crimes: Preventing Future Outrages, ed. Robert I. Rothberg. Washington, DC: Brookings Institution Press, 108-27.

Luck, Edward C. 2011a. "The Responsibility to Protect: The First Decade." Global Responsibility to Protect 3 (4): 387-99.

Luck, Edward C. 2011b. Interview with author (telephone), May 20.

Malloch-Brown, Mark. 2001. The Unfinished Global Revolution. London: Allen Lane.

Mayall, James. 2000. World Politics_Progress and Its Limits. Cambridge: Polity Press.

Mazower, Mark. 2011. “The New Foreign Policy Moralists Aren't as Far from Bush as They Think.” Guardian, May 20.

Mitter, Rana. 2003. "An Uneasy Engagement: Chinese Idea of Global Order and Justice in a Historical Perspective." In Order and Justice in International Relations, eds. Rosemary Foot, John L. Gaddis, and Andrew Hurrell. Oxford: Oxford University Press.

Mitter, Rana. 2004. A Bitter Revolution: China's Struggle with the Modern World. Oxford: Oxford University Press.

NATO (North Atlantic Treaty Organization). 2015. "NATO and Libya (Archived)." https:// www.nato.int/cps/ic/natohq/topics_71652.htm (accessed October 28, 2019).

NUPI (Norwegian Institute of International Affairs). 2019. "Assessing the Effectiveness of the UN Mission in South Sudan." https://effectivepeaceops.net/wp-content/ uploads/2019/04/EPON-UNMISS-Report-LOWRES.pdf (accessed October 30, 2019).

Parsons, Claudia. 2008. “France Urges U.N. Council to Act on Myanmar Cyclone.” Reuters, May 7.

Puri, Hardeep Singh. 2016. Perilous Interventions: The Security Council and the Politics of Chaos. New Dehli: Harper Collins.

Roberts, Adam. 2002-2003. “The Price of Protection." Survival 44 (4): 157-61.

RUSI. 2011. "Accidental Heroes: Britain, France and the Libya Operation." RUSI Report, September 22.

Sarkozy, Nicolas, Barrack Obama, and David Cameron. 2011. "Libya’s Pathway to Peace." International Herald Tribune, April 14.

Schnabel, Albrecht, and Ramesh Thakur, eds. 2000. Kosovo and the Challenge of 
Humanitarian Intervention. Tokyo: United Nations University Press.

Secretary-General's Internal Review Panel on UN Action in Sri Lanka. 2012. "Report of the Secretary-General's Internal Review Panel on UN Action in Sri Lanka." November. https://reliefweb.int/sites/reliefweb.int/files/resources/The_Internal_Review_Panel_ report_on_Sri_Lanka.pdf (accessed October 30, 2019).

Taylor-Norton, Richard. 2011. "SAS Troopers Help Co-Ordinate Rebel Attacks in Libya." Guardian, August 23.

Teitt, Sarah. 2011. "The Responsibility to Protect and China's Peacekeeping Policy." International Peacekeeping 18 (3): 298-312.

Thakur, Ramesh. 2011. "UN Breathes Life into 'Responsibility to Protect.” The Star, March 18. https://www.thestar.com/opinion/editorialopinion/2011/03/21/un_breathes_ life_intoresponsibility_to_protect.html\#targetText=On\%20March $\% 2017 \% 2 \mathrm{C} \% 20$ Security\%20Council,since\%20the\%201991\%20Gulf\%20War (accessed April 10, 2019).

Thakur, Ramesh, and Thomas G. Weiss. 2009. "R2P: From Idea to Norm-and Action?" Global Responsibility to Protect 1 (1): 22-53.

Todorov, Tzvetan. 2005. Hope and Memory. London: Atlantic Books.

UN (United Nations) General Assembly. 2018. "99th Plenary Meeting, Monday, 25 June 2018, 10 a.m., New York.” A/72/PV.99 (official records), June 25.

UN (United Nations) General Assembly. 2005. "2005 World Summit Outcome." A/RES/60/1, October 25.

UNHCR (United Nations High Commissioner for Refugees). 2018. "Global Trends: Forced Displacement in 2017.” June. https://www.unhcr.org/5b27be547.pdf (accessed October 30, 2019).

UN (United Nations) Human Rights Council. 2011. "Situation of Human Rights in Libyan Arab Jamahiriya.” A/HRC/S-15/L.1, February 27.

UN (United Nations) Secretary-General. 1999. "Report of the Secretary-General Pursuant to General Assembly Resolution 53/35 - The Fall of Srebrenica." A/54/549, November 15.

UN (United Nations) Secretary-General. 2000. "UN Secretary-General's Opening Remarks to Meeting with the North Atlantic Council." Brussels, October 5.

UN (United Nations) Secretary-General. 2005. "In Larger Freedom: Towards Development, Security, and Human Rights for All: Report of the Secretary-General." A/59/2005, March 21.

UN (United Nations) Secretary-General. 2007. "Letter from Secretary-General dated 31 August 2007 to the President of the Security Council." S/2007/721, December 7.

UN (United Nations) Secretary-General. 2009. "Implementing the Responsibility to Protect: Report of the Secretary-General." A/63/677, January 12.

UN (United Nations) Secretary-General. 2012. "Responsibility to Protect: Timely and Decisive Response, Report of the Secretary-General.” A/66/874-S/2012/578, July 25.

UN (United Nations) Secretary-General. 2018. "Secretary-General Remarks to the General Assembly Debate on the Responsibility to Protect.” June 25. https://www.un.org/sg/ en/content/sg/statement/2018-06-25/secretary-generals-remarks-general-assemblydebate-responsibility (accessed October 30, 2019).

UN (United Nations) Secretary-General. 2019. "Future Planning for the Protection of Civilian Sites in South Sudan: Report of the Secretary-General." S/2019/741, 
September 12.

UN (United Nations) Security Council. 1979. "2111st Meeting (verbatim records)." S/PV.2111, January 15.

UN (United Nations) Security Council. 1999. S/PV.3988 (verbatim records). March 24. https://www.securitycouncilreport.org/un-documents/document/kos-spv3988.php (accessed October 28, 2019).

UN (United Nations) Security Council. 2011a. “Security Council Resolution 1970.” S/RES/1970, February 26.

UN (United Nations) Security Council. 2011b. "Security Council Resolution 1973." S/RES/1973, March 17.

UN (United Nations) Security Council. 2011c. "6498th Meeting (verbatim records)." S/PV.6498, March 17.

UN (United Nations) Security Council. 2014a. "Security Council Resolution 2149.” S/RES/2149, April 10.

UN (United Nations) Security Council. 2014b. "Security Council Resolution 2150." S/RES/2150, April 16.

United States Department of State. 1994. "From U.S. Secretary of State to UN Mission New York, Talking Points for UNAMIR Withdrawal, April 15, 1994.” https://nsarchive2. gwu.edu/NSAEBB/NSAEBB53/ (accessed October 28, 2019).

United States Mission to the UN (United Nations). 2012. "Remarks by Ambassador Elizabeth M. Cousens, U.S. Representative on the UN Economic and Social Council and Alternate Representative to the UN General Assembly, at the UNGA Interactive Dialogue on the Responsibility to Protect." Washington D.C., September 5. http:// www.globalr2p.org/media/files/united-states-statement-2012.pdf (accessed October 30, 2019).

Viotti, Maria Luiza Ribeiro. 2011. "Annex to Letter Dated 9 November 2011 from the Permanent Representative of Brazil to the United Nations Addressed to the SecretaryGeneral: Responsibility while Protecting: Elements for the Development and Promotion of a Concept.” A/66/551-S/2011/701, November 11.

Welsh, Jennifer. 2006. "The Responsibility to Protect: Security of the Individual in International Society." In From Rights to Responsibilities: Rethinking Interventions for Humanitarian Purposes, eds. Oliver Jütersonke and Keith Krause. Geneva: PSIS.

Wood, Michael. 2006. "The Security Council and the Use of Force." Hersch Lauterpacht Memorial Lecture 2006, Cambridge University.

Mats Berdal is Professor of Security and Development in the Department of War Studies at King's College London. Between 2000 and 2003 he was the Director of Studies at the International Institute for Strategic Studies. Email: mats.berdal@kcl.ac.uk. 